\title{
The Relationship between International Marketing Resarch Process and Innovation Capacity
}

\author{
Dinçer Yarkın \\ Gediz Universitiy, Turkey \\ Yeliz Yeşil \\ Şeyh Edebali University, Turkey
}

Abstract

\begin{abstract}
Market orientation, investment on R\&D, leadership, culture are few key determinants of innovation capacity. According to our research, internationalization by exporting playing a role on improving innovation capacity, which requires proper international marketing research. In this study, qualitative data collected from exporters who are the members of Aegean Export Union in Izmir-Turkey. In depth interviews were conducted for investigating the relationship between international marketing research process and innovation capacity.
\end{abstract}

Keywords: International marketing research, innovation, innovation capacity

\section{Introduction}

One of the basic source of gaining competitive advantage is innovation. After Lisbon Meetings, targeting $3 \%$ R\&D expenditures in 2010, Innovation became top of the agendas of EU countries. According to EIS 2007, there are two main indicators of innovation outputs defined, the first one is applications; which consists of employment in high tech services, exports of high technology products, sales of new- to- market products, sales of new to firm products, employment in medium-high-tech manufacturing, the second one is intellectual property, includes EPO patents per million population, USPTO patents per million population, Triad patents per million population, community trademarks per million population and community designs per million population. In developing countries there has been seen growing attention on constituting awareness among firms' and most of them are struggling to increase the level of output indicators, defined in EIS 2007. In addition that, governments, provide Research \& Development and innovation incentives for increasing innovation capacity. Even these efforts, according to Global Innovation Index, Turkey is on the 54th line among 143 countries. Our claim is, even government incentives, without internationalization vision, companies cannot be competitive in innovation race. Our study showed that, internationalization intention, besides international marketing research for new markets, develops innovation vision naturally.

\section{Innovation}

Innovation consists of a new idea and its implementation into a new product, process, or service, leading to the dynamic growth of the national economy and the increase of employment as well as to creation of pure profit for the innovative business enterprise, A new idea could be a new product, service or method of production (technical innovation) or a new market, organizational structure or administrative system (administrative or organizational innovation (Urabe, Child \& Kagono, 1988;Damanpour \& Wischnevsky, 2006). Innovation is also, creating better or more effective processes and services or generating ideas or culture that will breed this creativity (Crumpton, 2012, )

Moving away from individualized business with local and regional customers and competitors, small- and medium-sized enterprises (SMEs) are increasingly required to be innovative to confront globalization and ever-increasing competition. (Thorgren, Wincent \& Örtqvist, 2009, p 149) According to Dobni (2008), innovation described in two ways, general and specific Examples of general innovations are , to have creative employees or be market leading, specifics are - referring to the types of behaviors and specific roles - in the form of culture, to be engaged by employees.

Innovation can be researched at various levels: the sectorial, regional, firm and project level (Verhees \& Meulenberg, 2004, p.136). In the firm level, forms of innovations are identified according to Johnson's (2001) typology. 
Figure 1: The Various Forms of Innovation

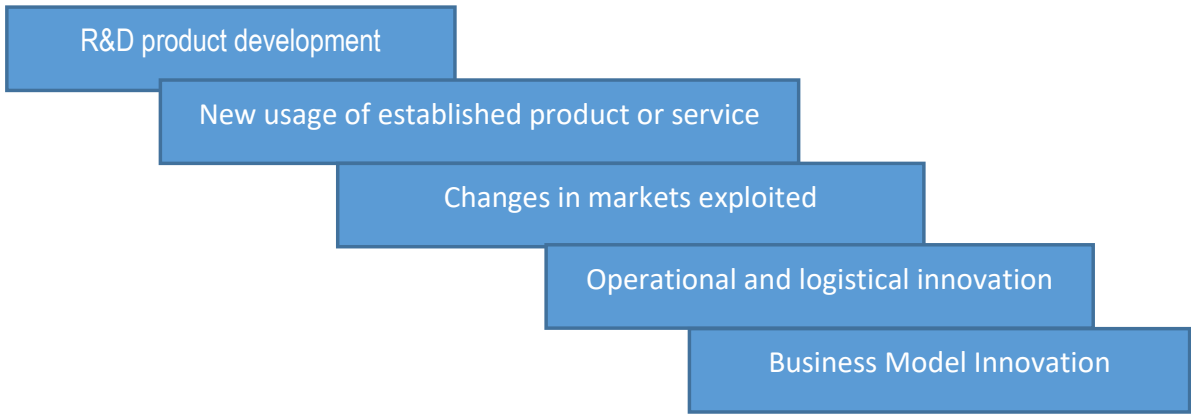

David Johnson, (2001) “What is innovation and entrepreneurship”Industrial Commercial and Training. 33(4), 135-140.

Oslo Manual one of the most referred document on Innovation literature, describing innovation basically in four ways, product, process, marketing and organizational.

Product Innovation:

According to Oslo Manual (2005),"A product innovation is the introduction of a good or service that is new or significantly improved with respect to its characteristics or intended uses". This product innovation strategy provides focus, guides the business's product development direction, and steers resource allocation, investment decisions and project selection(Cooper \&Edgett, 2009). Cooper (1999) defines 8 critical success factors for product innovation (see, Exhibit 1)

\begin{tabular}{|l|}
\hline Exhibit 1. Eight Actionable Critical Success Factors \\
\hline 1.Solid up-front homework-to define the product and justify the project \\
\hline 2.Voice of the customer- a slave-like dedication to the market and customer inputs throughout the project. \\
\hline 3.Product advantage-differentiated, unique benefits, superior value for the customer. \\
\hline 4.Sharp,stable and early product definition -before development begins. \\
\hline 5-A well-planned, adequately resourced, and proficiently executed launch. \\
\hline 6-Though go/kill decision points or gates-funnels,not tunnels \\
\hline 7-Accountable, dedicated, supported cross-functional teams with strong leaders. \\
\hline 8-An international orientation-international teams, multi-country market research, and global or "glocal" products \\
\hline
\end{tabular}

Robert Cooper (1999) FROM EXPERIENCE, The Invisible Success Factors in Product Innovation. Journal of Product Innovation Management, (16), 115-133.

Product innovation , for instance, entails, developing new goods and services (Khanzanchi, Lewis \& Boyer, 2007, p.871) Innovative products present great opportunities for businesses in terms of growth and expansion into new areas (Wang and Ahmed,2004)

\section{Process Innovation}

Oslo Manual defines (2005) process innovation as "implementation of a new or significantly improved production or delivery method which includes significant changes in techniques, equipment and/or software. The term process innovation 
encompasses the envisioning of new work strategies, the actual process design activity, and the implementation of the change in all its complex technological, human, and organizational dimensions (Davenport,1993).

\section{Marketing Innovation}

A marketing innovation is the implementation of a new marketing method involving significant changes in product design or packaging, product placement, product promotion or pricing(Oslo Manual, 2005).

Organizational Innovation

An organizational innovation is the implementation of a new organizational method in the firm's business practices, workplace organization or external relations (Oslo Manual ,2005). Innovations at the organizational level may involve the implementation of a new technical idea or a new administrative idea (Damanpour and Evan, 1984).

\section{International Marketing Research}

Marketing research is the systematic design, collection, analysis and reporting of data relevant to a specific marketing situation facing an organization and involved with the all phases of the information management process, including :the specification of what information is needed; the collection and analysis of the information; and the interpretation of the information with respect to objectives that motivated the study in the first place. (Kotler \& Armstrong, 2004; Lacobucci \&Churchill,2010)

The need for export marketing research will arise only when a company is genuinely interested in exporting its product (Beri, 2008)Increasing cultural diversity makes it important to collect information with regard to changing lifestyle and consumption patterns in different parts of the World (Craig and Douglas, 2005, p.1)International marketers conduct research to lower tisk involved in developing new products or pursuing new markets(Kleindl,2007)

There are two kinds of data being used in marketing research. Secondary data consists of sales records, cost information, distributor's reports, books, periodicals, government agencies' etc.(Wild \& Diggines, 2009, p.71) According to Patzer(1995) secondary data are being used for complementing primary data however, secondary data are being used for increasingly as the sole information to assist users of marketing rese arch in their decision making. Primary data are more related to intentions, attitudes, knowledge, psychological and personal , socio-economic characteristics of people(Churchill,1999).

\section{Research and Findings}

In this is study interpretive and exploratory approach is used for understanding , the role of international marketing research process on innovation capacity of exporting companies. Research sample was chosen from the companies who are the members of Aegean Export Union in Izmir- Turkey. There were 3 interviews recorded and implications collected in four topics as product innovation, process innovation, marketing innovation and organizational innovation.

\section{Product Innovation}

"In the beginning of our international marketing research process we are using internet resources.B2B e-marketplaces provide quite information about demands and supplies. By this way we have chance to compare our product specifications with other competitors. We use these information for product benchmarking" (M.O. Marketing Manager, Diffusor Disc Company).

\section{Process Innovation}

We are regularly attending international fairs. We are not only being there for customers, but also for seeing competitors. New production technologies can be seen in exhibitions. After coming back to country, we are coming together with our 
manufacturers for providing them information about new technologies. They are taking our observation in consideration and most of them starting to look over their processes even we are intermediary company.(R.P. CEO , Brush Exporting Company)

\section{Marketing Innovation:}

Pricing strategies are important for internationally acting firms. We are using B2B e- market places for checking selling leads. By this way we can compare our product prices with competitor's'. Before contacting potential buyers, we are evaluating our prices and avoiding negative feedbacks.(S.D.Export Manager, Textile Sector)

"Trademap is very useful for us, at the beginning stage of marketing research. We get information about where the strongest competitor's live in. After that we are deepening our research by using secondary data belonging to country which our competitors took place. After that we redesign our marketing strategies. (M.O. Marketing Manager, Diffusor Disc Company).

\section{Organizational Innovation}

We are starting marketing research from the competitors, their customer commitments and services on their web sites , provide information about their company structure. By using that information we established a team for installation. (M.O. Marketing Manager, Diffusor Disc Company).

Primary and secondary data are both has quite impact on innovation capacity. Face to face to meetings with customers in their places effects product and marketing innovations directly. Direct feedbacks from customers tend suppliers to evaluate functions and specifications of the products, manufactured by themselves. Industrial fairs provide crucial information about evaluating marketing mix of the companies. They have chance to compare their prices with other suppliers. By this way they are starting to consider productivity and production costs.

\section{Conclusion}

Efficient innovations depends on internal and external factors. Acting in local market is not enough for the inputs needed for innovation. From Lager's (2011) point of view, a company's internal and external innovation environment and its external business and competitive environment should guide its innovation strategy and programs. This will also prepare the conditions of open innovation, which is a paradigm that assumes that firms can and should use external ideas as well as internal ideas, and internal and external ideas paths to market as the firm look to advance their technology (Chesbrough, 2006).

Marketing innovations are mainly effected by secondary data. Evaluating demographics, cultural aspects of targeted society, provides valuable information about promotion strategies. Before entering new markets collecting data about country reports, supports promotion mix decisions. Researches show that a strong market focus and an effective marketing departments are important correlates of powerful innovation performance (Doyle\&Bridgewater,2012)

In our research we found that trader companies also provide information needed for innovations. According to Kjellberg, Azimont \& Reid (2015) many of the activities performed in market innovation processes are best characterized as intermediations; they serve to construct and maintain a network of actors and resources by linking, associating, connecting, integrating, etc. The number of commercial intermediaries increases, as well as the variety and the variability of markets and the customer's requirements for product quality, innovation and customization (Nassimbeni, 1999) 


\section{References}

[1] Beri, G.C. (2008) Marketing Research. New Delhi.Tata Mc Graw Hill.India.

[2] Craig, C., S., and Douglas, S.P. (2005) International Marketing Research. West Sussex, John Wiley and Sons Ltd.UK.

[3] Cooper ,R. G.(1999) FROM EXPERIENCE, The Invisible Success Factors in Product Innovation. Journal of Product Innovation Management, (16), 115-133.

[4] Cooper, R., G., Edgett, S.J. (2009) Product Innovation and Technology Strategy ,USA, Product Development Institute Inc.

[5] Chesbrogh, H.W. (2006) Open Innovation. Boston, Harvard Business School Publishing Corporation.USA.

[6] Churchill, G.A. (1999) Marketing research: methodological foundations.7th edition.Orlando:The Dryden Press

[7] Crumpton, M. (2012) Innovation and entrepreneurship. The Bottom Line, 25(3), 98-101.

[8] Damanpour, F., \& Evan, M., (1984) Organizational Innovation and Performance: The Problem of "Organizational Lag" Administrative Science Quarterly, 29(3)i 392-409.

[9] Damanpour, F., Wischnevsky, D.J. (2006) Research on Innovation in Organizations: Distinguishing innovationgenerating from innovation-adopting organizations. Journal of Engineering and Technology Management. 23(4), 269-291.

[10] Davenport, T.H. (1993) Process Innovation: Reengineering Work Through Information Technology. Ernst \&Young USA.

[11] Dobni, C.B. (2008) Measuring innovation culture in organizations. The development of a generalized innovation culture construct using exploratory factor analysis. European Journal of Innovation Management. 11(4). 539559.

[12] Doyle, P., Bridgewater, S. (2012) Innovation in Marketing, Routlege, London, Taylor and Francis Group

[13] Johnson, D. (2001) “What is innovation and entrepreneurship" Industrial Commercial and Training. 33(4), 135140.

[14] Khazanchi, S., Lewis, M.,W., Boyer, K.K. (2007) . Innovation supportive culture: The impact of organizational values on process innovation. Journal of Operations Management, 25, 871-884.

[15] Kjellberg, H., Azimont, F., Reid, E. (2015) Market Innovation Processes: Balancing stability and change.Industrial Marketing Management , (44), 4-12.

[16] Kleindl, B. (2007) International Marketing. OH, Thomson South-Western, USA

[17] Kotler P., Armstrong, G. (2004) Principles of Marketing, New Jersey, Pearson Education Ltd.,USA.

[18] Lacobucci, D., Churchill, G., (2010) Marketing Research, OH ,South-Western Cengage Learning, USA

[19] Lager,T. (2011) Managing Process Innovation From Idea Generation to Implementation, MA, Imperial College Press, USA.

[20] Nassimbeni, G. (1999) Technology, innovation capacity, and the export attitude of small manufacturing firms: a logit/tobit model. Research Policiy 30, 245-262.

[21] OSLO MANUAL (2005) Third Edition, European Commission.

[22] Patzer, G.L.(1995) Using Secondary Data In Marketing Research . Westport, Quorum Books, USA 
[23] Thorgren, S., Wincent, J., Örtqvist, D. (2009) Designing interorganizational networks for innovation:An empirical examination of network configuration, formation and governance. Journal of Engineering and Technology Management, 26, 148-166.

[24] Urabe, K., Child, J., Kagono, T. (1988) Innovation and Management, International Comparasions.Berlin, Walter and Gruyter \& Co., Germany.

[25] Verhees, F., J., H., M., Meulenberg, T.G. (2004) Market Orientation, Innovativeness, Product Innovation, and Performance in Small Firms. Journal of Small Business Management 42(2), 134-154.

[26] Wang, C.L. and Ahmed, P.K. (2004), "The development and validation of the organizational innovativeness construct using confirmatory factor analysis", European Journal of Innovation Management, 7 (4), pp. 303-13.

[27] Wild J.,Diggens, C. (2009) Marketing Research. Cape Town, Juta and Company Ltd. 